\title{
THE IMPACT OF MICROFINANCE SERVICES ON SOCIO- ECONOMIC WELFARE OF URBAN VULNERABLE HOUSEHOLDS IN MALAYSIA
}

\author{
Her-Loke Koh* \\ Multimedia University, Malaysia \\ Sakiru Adebola Solarin \\ University of Nottingham Malaysia \\ Yee-Yen Yuen \\ Multimedia University, Malaysia \\ Suganthi Ramasamy \\ Multimedia University, Malaysia \\ Guan-Gan Goh \\ Multimedia University, Malaysia
}

\begin{abstract}
The main objective of this study is to examine the effect of microfinance services on the socio-economic welfare of urban households in Malaysia. We distribute questionnaires to 400 respondents across three different urban areas in Malaysia in order to collect the relevant data for this study. Quota sampling is employed in the process of collecting the data. Incorporating income as a mediating variable into the model, the results show that most of the services provided by the microfinance institutions including microcredit, micro insurance and training have significant effect on socio-economic welfare. Income is also observed to have a significant impact on socio-economic welfare. With the exception of training, the microfinance services also have significant impact on income. The results further show that most of the microfinance services have indirect effect on welfare through income. The recommendations of this study are detailed in the body of the paper.
\end{abstract}

Keywords: Microfinance; Socio-Economic Welfare; Financial Services; Non-Financial Services.

Received: 1 October 2018

Accepted: 30 December 2020

https://doi.org/10.33736/ijbs.3752.2021

- Corresponding author: Faculty of Business, Multimedia University, Jalan Ayer Keroh Lama, 75450 Bukit Beruang, Melaka; Tel: +606-2523442; Email: herlokekoh@gmail.com 


\section{INTRODUCTION}

Malaysia is a middle-income country and covers two main regions: Peninsular Malaysia and East Malaysia (states of Sabah and Sarawak). The government of Malaysia embraced export-oriented industrialisation model in developing the country since the year 1970. The model, which emphasised on the development of the manufacturing sector, has successfully transformed the Malaysia's economy into an export-oriented one (Ministry of Finance, 2007). The government of Malaysia has set a long-term goal of becoming a developed nation in future. Thus, several policies and strategies have been formulated to support the nation's economic growth. Income inequality and poverty are banes to attaining the developmental objectives of any country. There are vulnerable households suffering from inadequate income for basic necessities of life. Vulnerable households are defined as families that encounter difficulties in fulfilling their basic livelihood needs (Mazvimavi \& Twomlow, 2009; Andersson \& D'Souza, 2014). Hence, a special group of households named B40 households was introduced in the Eleventh Malaysia Plan (2016-2020). B40 households represent the bottom 40 group with an estimated 11.7 million or $40 \%$ of the population in Malaysia that live with a household income of not more than RM 3,855 per month (Economic Planning Unit (EPU), 2015) ${ }^{1}$. The B40 household are affected by high indebtedness due to application for loan to augment their daily expenses. The people earned RM 3,000 or below have debts that are about 700\% of their earnings in 2013 (Bank Negara Malaysia, 2013). Moreover, B40 households face the issue of increment in living cost. It was reported that the B40 experienced $10.1 \%$ annual increase in the cost of living between 2009 and 2014 (EPU, 2015). According to World Bank (2019), the Gini Coefficient of Malaysia remained at 41 in both 2014 and 2015. In addition, they also need more resources to access basic amenities, healthcare, childcare and children's education. In particular, house rental in the urban areas account for half of the monthly salary earned by the poor urban households (Kaur, 2016).

Microfinance has been a part of poverty alleviation plans in helping the poor who usually would not qualify from the mainstream credit sector. There are many poor households in the world that are already getting benefits and financial services from microfinance institutions (Morduch \& Haley, 2002). Microfinance services are considered to be part of the tools in alleviating poverty in Malaysia. There are three leading organisations working towards poverty alleviation, namely: (i) Amanah Ikthiar Malaysia (AIM); (ii) Yayasan Usaha Maju (YUM); (iii) Tabung Ekonomi Kumpulan Usahawan National (TEKUN, or The Economic Fund for National Entrepreneurs Group). Established in $17^{\text {th }}$ of September 1987, AIM is the first microfinance institution in Malaysia with the core aim of helping the poor to develop their business by providing loan facilities. AIM implements the Grameen Bank framework where the main objectives are to provide financing, guidance and training to the poor. AIM and YUM are institutions which only give loans to those who are at or below the country's poverty line compared to TEKUN which does not only cover poor but also those above poverty line. AIM provides three types of economic loans for incomegenerating activities, namely: I-Mesra; I-Srikandi; and I-Wibawa. In addition, the organization provides: a recovery loan (I-Penyayang); an education loan (I-Bistari); and a housing/multipurpose loan (I-Sejahtera). The implementation of this program is based on the idea of 'trust' to monitor all members. AIM monitors the members, who are expected to attend weekly meeting organised by the institution. The meeting has promoted the capability of the participants to pay back the loans as the default rate was only $0.92 \%$ in year 2009 . AIM provides free interest credits to the borrowers,

${ }^{1} \mathrm{RM}$ is Malaysian ringgit and the average exchange rate in RM4.2 to US\$1 between Feb 28 and Mar 30, 2018 
which form themselves into groups of five and sequentially pledges against each other loans, in line with the model of the Grameen Bank. The total members of AIM as at April 2016 were 382,178 in Malaysia (Amanah Ikthiar Malaysia, 2016).

The main objective of this study is to identify the effect of microfinance services on the socioeconomic welfare of urban vulnerable households in Malaysia. The microfinance institutions provide five types of financial services which include microcredit, micro insurance, savings, training and social intermediation services. Likewise, this study would like to detect which microfinance services have effect on socio-economic welfare on urban vulnerable households. Hence, there are two academic contributions in this study. Firstly, unlike the majority of the previous studies that focus on the rural households, we are concentrating on urban households. Secondly, we use income as a mediating variable in our analysis. We are not aware of any previous research that has used income as a mediating variable. The focus is on 400 vulnerable households that are beneficiaries of the AIM services. The remainder of this paper is organised as follows. A review of the extant literature is done in the next section followed by discussion of the relationship among independent, dependent and mediating variables. The empirical approach is presented next, followed by results and bootstrapping tests. Finally, this paper concludes by discussing the implications of the findings and acknowledging the limitations of this study.

\section{LITERATURE REVIEW}

Socio-economic welfare is defined as a condition whereby a person or group is doing well or somewhat emphasises on a person's wellbeing or good (Frijerts \& Van Prag, 1999). The lowincome households are likely to have low purchasing power and low quality of life. Thus, there is a need for special assistance in improving the welfare of the low-income households. Microfinance programs are the potential platforms in enhancing the socio-economic welfare in society. Microfinance services play a vital platform in alleviating poverty, eradicating poverty and creating wealth among poor people. These are among the objectives established by several microfinance institutions. The positive impact of microfinance services on poverty has been highlighted by Alam (1988). The financial services provided by the microfinance programs are crucial inputs to enhance productivity at household level. It has been claimed that the microfinance services have the ability to improve income levels and enhance employment of household members (Okurut et al., 2004). Also, Mahjabeen (2008) stated that microfinance institutions enhanced income and consumption stream of the households, lessened income inequality. According to Mwewa (2013) and Mungai (2015), microfinance services could assist the poor in the creation of jobs because it provided the necessary capital for small scale enterprises.

There are studies that have considered the impacts of microfinance services on socio-economic welfare. One of the services that has been the focal point in the literature is microcredit. For instance, Wahid (1994) stated that credit services increase the capital available for the poor, thereby increasing their standards of living. It was also agreed that credit is an essential tool in assisting borrowers from avoiding the poverty trap (Hermes et al., 2011; Mokhtar, 2011; Nawai et al., 2011; Hamdan \& Hussin, 2012; Mwangi, 2015; Owuor 2015). The credit from microfinance programs also assisted poor households to overcome their liquidity issue and fund investments in agriculture, trades and business, increase income, construct and improve employment among households. Microfinance services are effective developmental tools in poverty reduction, income distribution 
and achievement of millennium development goals. Salia (2014) analysed the effects of microcredit schemes on welfare in Tanzania, Africa. The findings revealed that participation in microcredit schemes could lead to poverty eradication among women clients and also financed children's education and health services. Besides, microcredit provided more income stream for the poor and liberated them from poverty (Kireti \& Sakwa, 2014; Huque 2017).

Few studies have also considered the role of micro insurance including Beattie (2000) that argued that micro insurance is a social protection tool, which assisted low income households in escaping from poverty. Besides, Matul (2005) also stated that the affordability to own insurance for low income households was not only linked to their income but also to the appropriate supervision of their financial sources which has a significant impact on their access to micro insurance. Similarly, micro insurance is as significant to low income households as microcredit. Therefore, micro insurance is regarded as a powerful tool for low income households in enhancing their welfare (Collins et al., 2009; Shil \& Nath, 2013).

Savings (micro savings) is increasingly recognised as important to low income households as they must balance their cash flows in smoothening their daily consumption and future economic plan (Collins et al., 2009). Brannen (2010) conducted a study on the impact of micro savings on the welfare of the poor. The results showed that micro savings improved the welfare of the poor in Tanzania. Besides, Babajide et al. (2015) studied the influence of innovative micro savings service on welfare and business enterprise progress among low-income earners in Nigeria. The findings revealed that savings has a significant impact on welfare and also micro savings ensures that poverty-alleviation is achieved among low income households.

Training has also been considered in the literature. For instance, Hamdan and Hussin (2012) stated that the incorporation of entrepreneurial trainings had been considered as a powerful tool that can improve micro and small enterprises in South Africa and Malaysia. Previous studies also agreed with the fact that specific skills and training will assist most of the recipients of microfinance in overcoming different obstacles (Karnani, 2007; Paul et al., 2013). Saad (2010) focussed on the impact of microfinance activities on rural residents in Malaysia and the findings indicated that training activities from AIM lessens poverty, develops the education level of their children and enhances the health status of the poor households. However, the study only focused on rural states in Malaysia and did not cover the urban states or entire nation of Malaysia. Furthermore, AIM delivered a variety of training activities in enhancing their customer's talent to explore new income-generating activities, choosing suitable income-generating activities and enhancing their money management skills (Al-Shami et al., 2014; Al-Mamun et al. 2018).

The perception of group lending from microfinance is a pressing need nowadays in supporting the poor to find jobs and increase their standard of living. Group lending assists the poor to access microfinance services to better off their expenditure, gain access to market information and boost the activities of entrepreneurship (Attanasio et al., 2011). The loan from social intermediation service could generate more income to lenders (Al-Shami et al., 2014; Wairimu \& Mwilaria 2017). The study of Kireti and Sakwa (2014) examined the socioeconomic effects associated with the participation of women in the microfinance programs in Kenya. The findings revealed that the nonfinancial service of social intermediation service was able to smoothen their income level and improve their socioeconomic welfare. 
From the foregoing literature review, it is observed that a gap exists as most of the previous papers focus on the impact of microfinance institutions on the rural poor. Few of the previous studies have shown that microcredit has direct relationship on socio-economic welfare (Nader, 2008). In addition, Shil and Nath (2013) revealed significant relationship between micro insurance and socio-economic welfare. Moreover, Haile et al. (2012) has evidenced the relationship between savings and socio-economic welfare. Last but not least, Al-Shami et al. (2014) has shown significant relationship microfinance services (training and social intermediation service) on socioeconomic welfare. However, none of the previous studies has used income as a mediating variable, when the impact of microfinance services on socioeconomic welfare is considered.

\section{METHODOLOGY}

The target respondents of this study are the household recipients of AIM's services in Penang, Kuala Lumpur and Johor Bahru. According to report from Department of Statistics Malaysia (DoSM) (2010), Penang, Kuala Lumpur and Johor Bahru are considered as the top three urbanised states in Malaysia. Hence, a total of 400 respondents are selected from these three different geographic areas in Peninsular Malaysia. However, due to restriction and confidentiality of information, the data for population of AIM's recipients is not available. Hence, we represent AIM population figure with the figure for the total B40 population in the urban areas. According to DoSM (2017), the population of B40 households in the urban area is 1,701,000. With a similar number of population, Rulindo and Pramanik (2013) and Macha et al. (2018) have used 400 sample size. Hence, the sample size for this study is 400 microfinance recipients. The sample size is consistent with Krejcie and Morgan (1970) that recommended that the minimum number of sample size for a population size of $1,000,000$ is almost 400 .

Primary data collection approach is used in this study. The data was collected via questionnaires in selected study areas. The questionnaires were adopted from previous studies (Durrani et al., 2011; Omoro \& Omwange, 2013; Kireti \& Sakwa, 2014). The approach of survey questionnaires was applied in this study as this approach provided an efficient way in collecting data. Patten (2016) indicated that the construction of questionnaire is superior to interview method because using questionnaire enables the researcher to collect data from several respondents simultaneously. Many of the previous studies such as Nawai et al. (2011), Omar et al. (2012) and Al-Mamun et al. (2014) have also used the survey questionnaire approach for data collection.

The quota sampling approach was used in this study, which is similar to that applied in a research carried out by Hassan et al. (2012), where the samples were selected from three geographic areas. The three states for this study are Penang, Kuala Lumpur, and Johor Bahru in Peninsular Malaysia. Malaysia was selected in this study due to convenience of gathering data and other required information. According to the DoSM (2017), these three states are considered as the most urbanised states in Malaysia. Based on the statistics of population, Kuala Lumpur reported the highest population at $91.4 \%$, followed by Penang with $90.8 \%$, and Johor Bahru with $71.8 \%$. The AIM was chosen in this study as the objectives of its establishment are to improve the welfare of the poor in Malaysia. Questionnaires were distributed to microfinance recipients, who gathered at the headquarters of AIM in the three states. They were given sufficient time to answer the questionnaires. Statistical Package for Social Science (SPSS) was used to measure the descriptive analysis while Partial Least Squares structural equation modeling (PLS-SEM) was used to 
determine the path correlation between the variables. Since the objective of this study is to predict key target constructs or identify key driver constructs, PLS-SEM is the best choice of analysis (Hair Jr et al., 2016). PLS-SEM is highly suitable for prediction-oriented study, requires small sample size, and is appropriate for non-normally distributed of data (Hair Jr et al., 2016). Previous studies have also adopted PLS-SEM in examining the relationship between microfinance services and socio-economic welfare (Amin et al., 2013; Tsafe \& Rahman, 2014; Hoamid et al., 2017). Figure 1 shows the research framework.

Figure 1: Research Framework

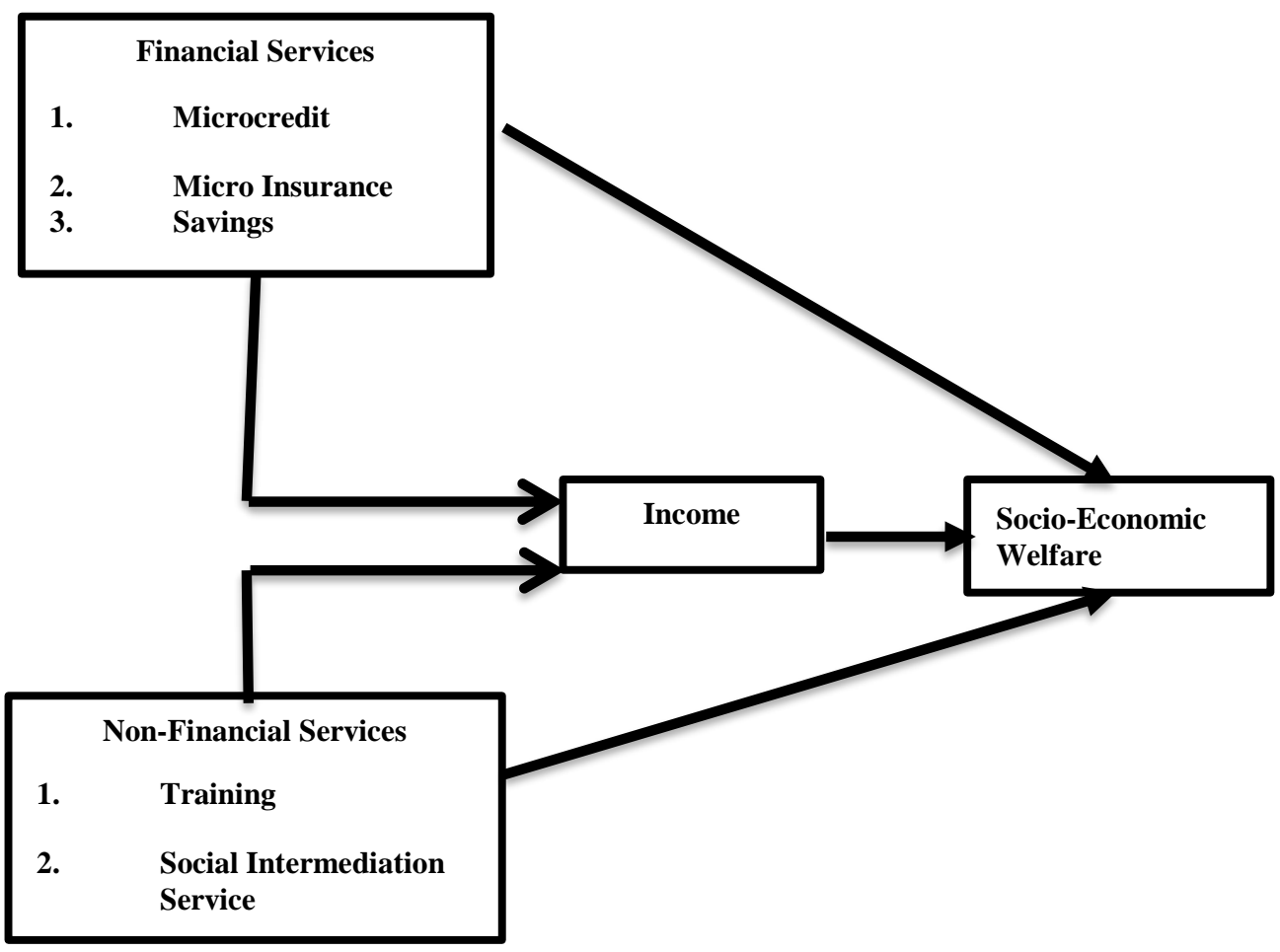

\section{Items of the Variables}

The measurement model comprises of the following constructs and items adapted from literature reviews in Table 1 and will be validated in terms of construct composite reliability and discriminant validity in Table 4 and 5. 
Table 1: Measurement Model

\begin{tabular}{|c|c|c|c|}
\hline Constructs & & Items & Sources \\
\hline \multirow{5}{*}{ Welfare } & W1 & $\begin{array}{l}\text { Microfinance services enhance living } \\
\text { standards of households. }\end{array}$ & \multirow{5}{*}{$\begin{array}{l}\text { Omoro and } \\
\text { Omwange, (2013) }\end{array}$} \\
\hline & W2 & $\begin{array}{l}\text { Microfinance services improve children } \\
\text { education standards. }\end{array}$ & \\
\hline & W3 & Microfinance services assist in improving & \\
\hline & W4 & $\begin{array}{l}\text { Microfinance services assist urban } \\
\text { households start businesses. }\end{array}$ & \\
\hline & W5 & $\begin{array}{l}\text { Microfinance services enable households' } \\
\text { access basic needs. }\end{array}$ & \\
\hline \multirow{5}{*}{ Microcredit } & MC1 & Microcredit increases stock of enterprise. & \multirow{5}{*}{$\begin{array}{l}\text { Kireti and Sakwa, } \\
(2014)\end{array}$} \\
\hline & MC2 & $\begin{array}{l}\text { Microcredit increases output of the } \\
\text { enterprise. }\end{array}$ & \\
\hline & MC3 & $\begin{array}{l}\text { Microcredit enables to start a new } \\
\text { business. }\end{array}$ & \\
\hline & MC4 & Microcredit ensures children attend school. & \\
\hline & MC5 & $\begin{array}{l}\text { Microcredit leads to ability to access health } \\
\text { centres. }\end{array}$ & \\
\hline \multirow{5}{*}{$\begin{array}{l}\text { Micro } \\
\text { Insurance }\end{array}$} & MI1 & $\begin{array}{l}\text { Micro insurance builds strong trust bonds } \\
\text { with group members. }\end{array}$ & \multirow{5}{*}{$\begin{array}{l}\text { Kireti and Sakwa, } \\
(2014)\end{array}$} \\
\hline & MI2 & $\begin{array}{l}\text { Micro insurance creates more social } \\
\text { network bonds within community. }\end{array}$ & \\
\hline & MI3 & $\begin{array}{l}\text { Micro insurance motivates participation in } \\
\text { developmental social activities. }\end{array}$ & \\
\hline & MI4 & $\begin{array}{l}\text { Micro insurance enables better study for } \\
\text { children. }\end{array}$ & \\
\hline & MI5 & $\begin{array}{l}\text { Micro insurance enables reduction of risks } \\
\text { exposure. }\end{array}$ & \\
\hline \multirow{5}{*}{$\begin{array}{l}\text { Social } \\
\text { Intermediation } \\
\text { Service }\end{array}$} & SIS1 & $\begin{array}{l}\text { Social intermediation service enables } \\
\text { management efficiencies and cost of } \\
\text { operating enterprises. }\end{array}$ & \multirow{5}{*}{$\begin{array}{l}\text { Kireti and Sakwa, } \\
(2014)\end{array}$} \\
\hline & SIS2 & $\begin{array}{l}\text { Social intermediation service eases } \\
\text { production constraints and stabilises } \\
\text { income. }\end{array}$ & \\
\hline & SIS3 & $\begin{array}{l}\text { Social intermediation service enables } \\
\text { better social skills on good relation thus } \\
\text { building social networks for market } \\
\text { growth. }\end{array}$ & \\
\hline & SIS4 & $\begin{array}{l}\text { Social intermediation service ensures good } \\
\text { practice of preventive health measure for } \\
\text { healthy wellbeing. }\end{array}$ & \\
\hline & SIS5 & $\begin{array}{l}\text { Social intermediation service enables to } \\
\text { obtain loans easily as they belong and } \\
\text { guarantee by the members of the group. }\end{array}$ & \\
\hline
\end{tabular}


Table 1 (cont'): Items of the Variables

\begin{tabular}{|c|c|c|c|}
\hline \multirow{5}{*}{ Savings } & SV1 & $\begin{array}{l}\text { Savings increase capital resource to cover } \\
\text { health services. }\end{array}$ & \multirow{5}{*}{$\begin{array}{l}\text { Kireti and Sakwa, } \\
\text { (2014) }\end{array}$} \\
\hline & SV2 & $\begin{array}{l}\text { Savings increase capital resource to cater } \\
\text { for children's education. }\end{array}$ & \\
\hline & SV3 & Savings enables repayment of loan. & \\
\hline & SV4 & $\begin{array}{l}\text { Savings smoothen irregular income to } \\
\text { manage consumption needs. }\end{array}$ & \\
\hline & SV5 & $\begin{array}{l}\text { Savings increase income levels to generate } \\
\text { more wealth. }\end{array}$ & \\
\hline \multirow{5}{*}{ Training } & TR1 & Trainings frequently provided. & \multirow{5}{*}{$\begin{array}{l}\text { Maru and Chemjor, } \\
\text { (2013) }\end{array}$} \\
\hline & TR2 & Trainings improve business performance. & \\
\hline & TR3 & Trainings enable successful loan usage. & \\
\hline & TR4 & Trainings are reasonable in terms of cost. & \\
\hline & TR5 & $\begin{array}{l}\text { Trainings are always relevant to the } \\
\text { trainees. }\end{array}$ & \\
\hline \multirow{5}{*}{ Income } & $\mathrm{IC} 1$ & $\begin{array}{l}\text { My household income is higher than before } \\
\text { taking loan. }\end{array}$ & \multirow{5}{*}{$\begin{array}{l}\text { Durrani } \\
(2011)\end{array}$} \\
\hline & IC2 & $\begin{array}{l}\text { Purchasing power has increased after } \\
\text { getting facilities of micro financing. }\end{array}$ & \\
\hline & IC3 & $\begin{array}{l}\text { Consumption level has increased by } \\
\text { getting microfinance. }\end{array}$ & \\
\hline & IC4 & $\begin{array}{l}\text { Income has increased after inception of } \\
\text { microfinancing. }\end{array}$ & \\
\hline & IC5 & $\begin{array}{l}\text { Role in income contribution in the } \\
\text { household is improved after availing micro } \\
\text { financing. }\end{array}$ & \\
\hline
\end{tabular}

\section{RESULTS AND DISCUSSION}

The results in Table 2 reveal that about $75 \%$ of the respondents are between the age of 26 and 50 years. This indicates that majority of these household receivers' category are in working-age category. Nevertheless, only $2.4 \%$ of the respondents associating to the age group 61 and above were recorded. The percentage in age group 25 or below and $51-60$ years are $5.3 \%$ and $17.8 \%$.

Table 2: Distribution of Respondents by Age Group

\begin{tabular}{lll}
\hline \hline Age Group & Frequency $(\mathbf{N})$ & Percentage $(\%)$ \\
\hline 25 or below & 21 & 5.3 \\
$26-35$ & 84 & 21.0 \\
$36-50$ & 214 & 53.5 \\
$51-60$ & 71 & 17.8 \\
61 and above & 10 & 2.4 \\
\hline \hline
\end{tabular}

The results in Table 3 indicate that almost $83 \%$ of the respondents earn an income between RM 1,500 to RM 3,855. Only $17.5 \%$ of the respondents have earned less than RM 1,500 during collection period. 
Table 3: Household Current Gross Monthly Income of the Respondents

\begin{tabular}{lll}
\hline \hline Household Current Gross Monthly Income & Frequency (N) & Percentage (\%) \\
\hline Less than RM 1,500 & 70 & 17.5 \\
RM 1,500 to < RM 2,500 & 147 & 36.6 \\
RM 2,500 to < RM 3,855 & 183 & 45.9 \\
\hline \hline
\end{tabular}

\subsection{Measurement Model}

The composite reliability and internal consistency assessed the reliability of construct measurement. The reliability of each construct was evaluated by the composite reliability with the cutoff value of 0.7 (Fornell \& Larcker, 1981; Hair Jr et al., 2016). On the other hand, the convergent validity was tested by Average Variance Extracted (AVE) with the recommended cut-off value of 0.5 and also each item loadings with the recommended cut-off value of more than 0.7 (Fornell \& Larcker, 1981; Hair Jr et al., 2016). This indicates adequate convergent validity as all items fulfill the requirements. Figure 2 and Table 4 shows the results for items loading, average variance extracted (AVE) and construct composite reliability (CR) of this study. The results reveal that all constructs' items loading, reliability and AVE are above the recommended levels.

Figure 2: Structural and Measurement Model

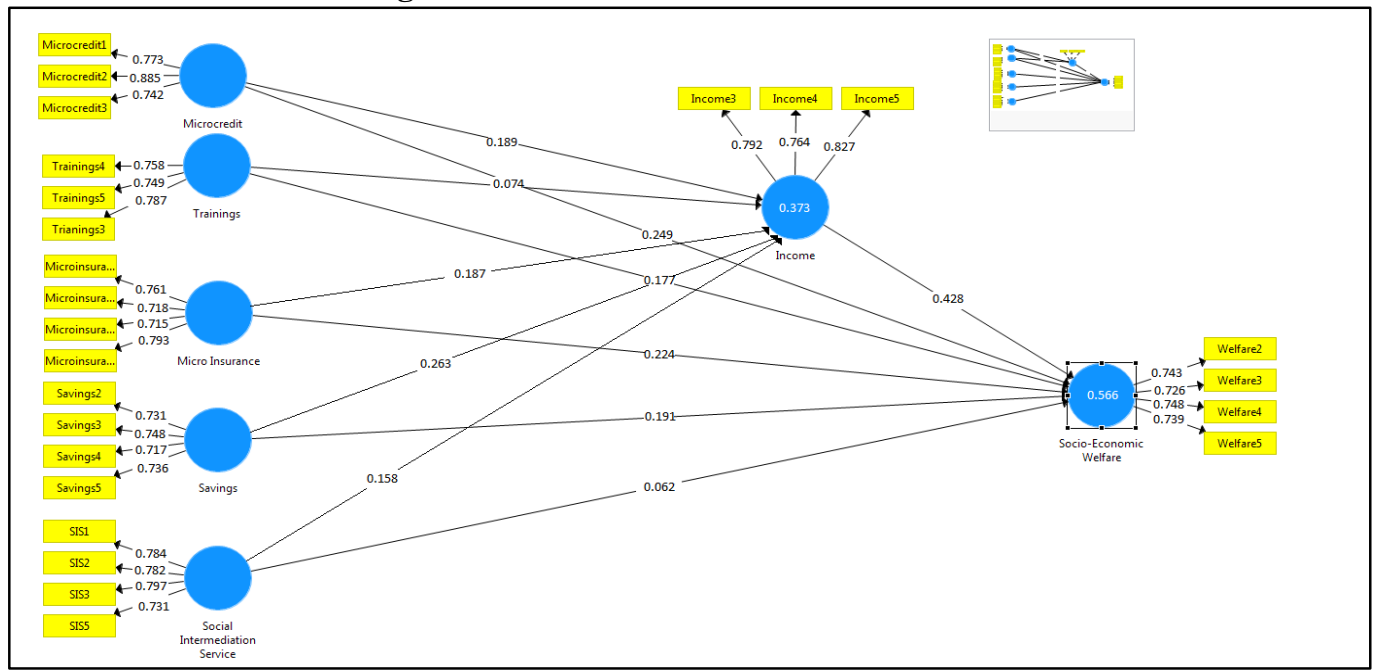

Table 4: Items Loading, Average Variance Extracted (AVE) and Construct Composite Reliability (CR)

\begin{tabular}{lcccc}
\hline \hline Constructs & $\begin{array}{c}\text { Measurement } \\
\text { Items }\end{array}$ & $\begin{array}{c}\text { Items } \\
\text { Loading }\end{array}$ & AVE & $\begin{array}{c}\text { Composite } \\
\text { Reliability }\end{array}$ \\
\hline \multirow{3}{*}{ Welfare } & W2 & 0.743 & & \\
& W3 & 0.726 & 0.562 & 0.837 \\
\hline
\end{tabular}




\begin{tabular}{|c|c|c|c|c|}
\hline Constructs & $\begin{array}{l}\text { Measurement } \\
\text { Items }\end{array}$ & $\begin{array}{c}\text { Items } \\
\text { Loading }\end{array}$ & AVE & $\begin{array}{l}\text { Composite } \\
\text { Reliability }\end{array}$ \\
\hline & W5 & 0.739 & & \\
\hline \multirow{3}{*}{ Microcredit } & $\mathrm{MC} 1$ & 0.773 & \multirow{3}{*}{0.651} & \multirow{3}{*}{0.843} \\
\hline & MC2 & 0.885 & & \\
\hline & MC3 & 0.742 & & \\
\hline \multirow{4}{*}{$\begin{array}{l}\text { Micro } \\
\text { Insurance }\end{array}$} & MI2 & 0.761 & \multirow{4}{*}{0.563} & \multirow{4}{*}{0.836} \\
\hline & MI3 & 0.718 & & \\
\hline & MI4 & 0.715 & & \\
\hline & MI5 & 0.793 & & \\
\hline \multirow{4}{*}{$\begin{array}{l}\text { Social } \\
\text { Intermediation } \\
\text { Service }\end{array}$} & SIS1 & 0.784 & \multirow{4}{*}{0.549} & \multirow{4}{*}{0.829} \\
\hline & SIS2 & 0.782 & & \\
\hline & SIS3 & 0.797 & & \\
\hline & SIS5 & 0.731 & & \\
\hline \multirow{4}{*}{ Savings } & SV2 & 0.731 & \multirow{4}{*}{0.571} & \multirow{4}{*}{0.842} \\
\hline & SV3 & 0.748 & & \\
\hline & SV4 & 0.717 & & \\
\hline & SV5 & 0.736 & & \\
\hline \multirow{3}{*}{ Training } & TR3 & 0.758 & \multirow{3}{*}{0.631} & \multirow{3}{*}{0.836} \\
\hline & TR4 & 0.749 & & \\
\hline & TR5 & 0.787 & & \\
\hline \multirow{3}{*}{ Income } & IC3 & 0.792 & \multirow{3}{*}{0.635} & \multirow{3}{*}{0.839} \\
\hline & IC4 & 0.764 & & \\
\hline & IC5 & 0.827 & & \\
\hline
\end{tabular}

Discriminant validity is a test to ensure that the value of AVE must at least be above the threshold value of 0.50 and the square root of the AVE also should higher than all other cross correlations (Fornell \& Larcker, 1981; Chin, 1998; Chin 2010). Table 5 depicts that the diagonal values (bold) are greater than the corresponding correlation values for each rows and columns. Thus, the discriminant validity is assured.

Table 5: Discriminant Validity Analysis

\begin{tabular}{|c|c|c|c|c|c|c|c|c|}
\hline$\dot{\mathbf{z}}$ & $\frac{\frac{y}{0}}{\frac{\pi}{\pi}}$ & $\begin{array}{l}\mathscr{\Xi} \\
\stackrel{\Xi}{\Xi} \\
\Xi\end{array}$ & 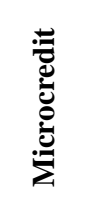 & 导 & : & 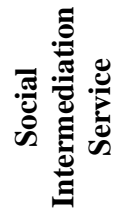 & & 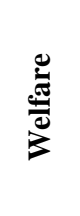 \\
\hline 1 & Income & 0.796 & & & & & & \\
\hline 2 & Microcredit & 0.563 & 0.813 & & & & & \\
\hline 3 & Micro Insurance & 0.526 & 0.589 & 0.749 & & & & \\
\hline 4 & Savings & 0.439 & 0.496 & 0.541 & 0.757 & & & \\
\hline 5 & $\begin{array}{c}\text { Social Intermediation } \\
\text { Service }\end{array}$ & 0.548 & 0.527 & 0.524 & 0.535 & 0.739 & & \\
\hline 6 & Training & 0.464 & 0.413 & 0.453 & 0.516 & 0.514 & 0.792 & \\
\hline 7 & Welfare & 0.437 & 0.612 & 0.614 & 0.597 & 0.594 & 0.483 & 0.753 \\
\hline
\end{tabular}

Diagonals (in bold) represent the squared root of Average Variance Extracted (AVE) while other entries represent correlations. 


\subsection{Structural Model}

The structural model stipulates the information about the coefficients of sizes $\left(\mathrm{R}^{2}\right)$, and path coefficients of all variables. The results of Table 6 reveal that $\mathrm{R}^{2}$ for dependent variable (welfare) and mediating variable (income) are 0.566 and 0.373 , respectively. Hence, the research explained $56.6 \%$ of total variance of all predictors to welfare. Also, income was $37.3 \%$ determined by all independent variables.

Table 6: Coefficients of Sizes and Predictive Relevance Analysis

\begin{tabular}{ll}
\hline \hline Variables & Coefficients of Sizes, $\mathbf{R}^{\mathbf{2}}$ \\
\hline Income & $37.3 \%$ \\
Welfare & $56.6 \%$ \\
\hline \hline
\end{tabular}

The results in Table 7 illustrate the significance of direct path coefficients. This result shows the importance microfinance services in enhancing the socio-economic welfare as well as income of the microfinance recipients. Based on the Table 7, it is shown that income is observed to have a significant impact on socio-economic welfare $(\beta=0.428 ; \mathrm{p}<0.001)$. Microcredit has significant effect on income $(\beta=0.189 ; p=0.001)$ and socio-economic welfare $(\beta=0.247 ; p<0.001)$. Micro insurance has significant effect on income $(\beta=0.187 ; p=0.001)$ and socio-economic welfare $(\beta=0.224 ; p<0.001)$. Savings has significant effect on income $(\beta=0.263 ; p<0.001)$ and socioeconomic welfare $(\beta=0.191 ; p<0.001)$. Training has significant effect on socio-economic welfare $(\beta=0.177 ; p<0.001)$. Social intermediation service has significant effect on income $(\beta=0.158$; $\mathrm{p}=0.006$ ). The foregoing are the only significant path coefficients of this study. This result indicates the significant role of all microfinance services (except social intermediation service) on socioeconomic welfare. In addition, this result also shows the significant role of all microfinance services (except training) on income. These results are consistent with previous studies including the works of (Li, Gan, \& Hu, 2011; Shil \& Nath, 2013; Sarpong, 2014; Mbithi, 2016; Seng, 2017; Wairimu \& Mwilaria 2017).

Table 7: Significance of Direct Path Coefficients

\begin{tabular}{lcccc}
\hline \hline & $\begin{array}{c}\text { Standardised } \\
\text { Beta }\end{array}$ & $\begin{array}{c}\text { Standard } \\
\text { Error }\end{array}$ & t-statistics & p-values \\
\hline Income -> Welfare & 0.428 & 0.044 & 7.675 & $<0.001$ \\
MC -> Income & 0.189 & 0.051 & 3.405 & 0.001 \\
MC -> Welfare & 0.249 & 0.049 & 5.233 & $<0.001$ \\
MI -> Income & 0.187 & 0.054 & 3.374 & 0.001 \\
MI -> Welfare & 0.224 & 0.055 & 4.035 & $<0.001$ \\
SV -> Income & 0.263 & 0.061 & 4.453 & $<0.001$ \\
SV -> Welfare & 0.191 & 0.053 & 3.938 & $<0.001$ \\
TR -> Income & 0.074 & 0.041 & 0.782 & 0.359 \\
TR -> Welfare & 0.177 & 0.048 & 4.876 & $<0.001$ \\
SIS -> Income & 0.158 & 0.050 & 2.635 & 0.006 \\
SIS -> Welfare & 0.062 & 0.042 & 0.796 & 0.395 \\
\hline \hline
\end{tabular}


The results in Table 8 display the significance of indirect path coefficients. The mediating variable of income was added to five relevant paths of coefficients. It is shown that income significantly mediates the relationship between several microfinance services (microcredit, micro insurance, training and social intermediation service) and welfare, which is a result that is not available in the previous papers. Saving is the only microfinance service that income does not mediate its relationship with welfare.

Table 8: Significance of Indirect Path Coefficients

\begin{tabular}{lcccc}
\hline \hline & $\begin{array}{c}\text { Standardised } \\
\text { Beta }\end{array}$ & $\begin{array}{c}\text { Standard } \\
\text { Error }\end{array}$ & t-statistics & p-values \\
\hline MC -> Income -> Welfare & 0.076 & 0.020 & 2.787 & 0.005 \\
MI -> Income -> Welfare & 0.091 & 0.017 & 3.324 & 0.001 \\
SV -> Income -> Welfare & 0.032 & 0.043 & 0.743 & 0.412 \\
TR -> Income -> Welfare & 0.068 & 0.018 & 2.622 & 0.009 \\
SIS -> Income -> Welfare & 0.109 & 0.031 & 3.792 & $<0.001$ \\
\hline \hline
\end{tabular}

Next, we consider the justification of the foregoing results, which is done on variable basis. For instance, there is evidence that more microcredits will increase the disposable income and enhance the socio-economic welfare among microfinance recipients. The result is not surprising given the fact that microcredits may help in income generation for the business and contribute to the enrichment of living standard (Li et al., 2011). Micro insurance has been proven to have the ability of increasing income and enhancing the socio-economic welfare among microfinance recipients. Micro insurance is able to mitigate the associated life and health risks as well as smoothen the daily cash flows among the microfinance recipients (Shil \& Nath, 2013). In addition, it is an essential social protection tool in safeguarding their standard of living and business performance. Thus, this may help in income generation for the business and enhancing their standard of living.

\section{CONCLUSION}

The main objective of this study was to examine the ideal microfinance services which enhance the socio-economic welfare of urban households in Malaysia. The results of this study confirmed the positive effect of microcredit, micro insurance, social intermediation service and training on socio-economic welfare. These results supported the hypothesis of the study by affirming the importance of microfinance services in enhancing the socio-economic welfare of urban households' poverty. This is aligned with the goals of the New Economic Model (2010) and the 11th Malaysia Plan (EPU, 2015) and also complement the efforts required under the National B40 Protection Scheme, 2019.

The study found out that majority of the households is between the age group of 36 to 50. Most of them have at least secondary education with only minority having post-secondary education. In addition, this study found out that many of the urban households engage in self-employed businesses by starting up their own small businesses. This resulted in their gross monthly income to be between the ranges of RM 1,500 to RM 4,000 only. The study also confirmed that most of the microfinance services provided by AIM are very significant in increasing their sources of 
income as well as enhancing their socio-economic welfare. Saving is the only microfinance service that income does not mediate its relationship with welfare.

There are several recommendations emanating from the results of this paper. Microfinance institutions should always strive to promote the quality of products and services to meet the different needs of the borrowers. This may help to enhance the participation rate in their programmes in order to achieve poverty alleviation. Nevertheless, government should also be continuously funding the microfinance institutions in order to assist their operational maintenance. This will indirectly enhance the standard of living for the society too. The government of Malaysia through AIM should extend promoting microfinance programmes in enhancing the wellbeing for the urban households in Malaysia. The government and relevant authorities have the responsibility in generating sustainable and favourable policy on microfinance institutions operations. These policies will assist them to ensure more urban households participate in microfinance programmes. This can indirectly have multiple effects on households' socio-economic welfare. Microfinance will perhaps likely to empower people by providing them with more confidence and assisting them financially in their businesses.

There are several avenues through which future studies can improve the current exercise. For instance, this study has been able to collect data from three states in Malaysia. Future studies should cover more geographic areas.

\section{ACKNOWLEDGEMENT}

This work was financially supported by the Ministry of Higher Education (MOHE, Malaysia) under the grant no: FRGS/1/2015/SS08/MMU/02/1.

\section{REFERENCES}

Alam, J. (1988). Rural Poor Program in Bangladesh. UNDP, Dhaka, Bangladesh.

Al-Mamun, A., Mazumder, M. N. H., \& Malarvizhi, C. A. (2014). Measuring the Effect of Amanah Ikhtiar Malaysia's Microcredit Programme on Economic Vulnerability among Hardcore Poor Households. Progress in Development Studies, 14(1), 49-59.

Al-Mamun, A., Ibrahim, M. A. H. B., Muniady, R., Ismail, M. B., Nawi, N. B. C., \& Nasir, N. A. B. M. (2018). Development programs, household income and economic vulnerability: A study among low-income households in Peninsular Malaysia. World Journal of Entrepreneurship, Management and Sustainable Development, 14(4), 353-366.

Al-Shami, S. S. A., Majid, I. B. A., Rashid, N. A., \& Hamid, M. S. R. B. A. (2014). Conceptual framework: The role of microfinance on the wellbeing of poor people cases studies from Malaysia and Yemen. Asian Social Science, 10(1), 230-242. doi:10.5539/ass.v10n1p230

Amanah Ikthiar Malaysia. (2016). Amanah Ikhtiar Malaysia. http://aim.gov.my/

Amin, H., Abdul-Rahman, A. R., \& Abdul-Razak, D. (2013). An Integrative Approach for Understanding Islamic Home Financing Adoption in Malaysia. International Journal of Bank Marketing, 31(7), 544-573. 
Andersson, J. A., \& D'Souza, S. (2014). From adoption claims to understanding farmers and contexts: A literature review of Conservation Agriculture (CA) adoption among smallholder farmers in southern Africa. Agriculture, Ecosystems and Environment, 187, 116-132.

Attanasio, O., Augsburg, B., De Haas, R., Fitzsimons, E., \& Harmgart, H. (2011). Group lending or individual lending? Evidence from a randomised field experiment in Mongolia. (IFS Working Papers No. W11/20). Institute of Fiscal Studies. https://doi.org/10.1920/wp.ifs.2011.1120

Babajide, A. A., Taiwo, J. N., \& Isibor, J. A. (2015). Microsavings Mobilization Innovations and Poverty Alleviation in Nigeria. Mediterranean Journal of Social Sciences, 6(4), 375-387.

Beattie, R. (2000). Social protection for all: But how?. International Labour Review, 139(2), 129148.

Brannen, C. (2010). An impact study of the Village Savings and Loan Association (VSLA) program in Zanzibar, Tanzania (Doctoral dissertation, Wesleyan University, Connecticut). https://citeseerx.ist.psu.edu/viewdoc/download?doi=10.1.1.204.1554\&rep=rep1\&type=p $\underline{\text { df }}$

Chin, W. W. (1998). Commentary: Issues and opinion on structural equation modeling. MIS Quarterly, 22(1), vii-xvi.

Chin, W. W. (2010). How to write up and report PLS analyses. In Handbook of partial least squares (pp. 655-690). Springer Berlin Heidelberg.

Collins, D., Morduch, J., Rutherford, S., \& Ruthven, O. (2009). Portfolios of the poor: How the world's poor live on $\$ 2$ a day. Princeton: Princeton University Press.

Department of Statistic Malaysia. (DoSM) (2010). Monthly statistical bulletin. http://www.statistics.gov.my

Department of Statistics Malaysia. (DoSM) (2017). Household Income and Basic Amenities Survey 2016. https://www.dosm.gov.my/v1/index.php?r=column/cthemeByCat\&cat=120\&bul $\underline{\mathrm{id}=\text { RUZ5REwveU1ra1hGL21JWV1PRmU2Zz09\&menu_id=amVoWU54UT10a21NW }}$ mdhMjFMMWcyZz09

Durrani, M. K. K., Usman, A., Malik, M. I., \& Ahmad, S. (2011). Role of Micro Finance in Reducing Poverty: A Look at Social and Economic Factors. International Journal of Business and Social Science, 21(2), 138-144.

Economic Planning Unit. (EPU) (2015). The Eleventh Malaysian Plan (2016-2020). Putrajaya: Malaysia.

Fornell, C., \& Larcker, D. F. (1981). Evaluating structural equation models with unobservable variables and measurement error. Journal of marketing research, 18(1), 39-50.

Frijters, P., \& Van Praag, B. (1999). The Measurement of Welfare and Well-being: The Leyden Approach. Foundations of Hedonic Psychology, Scientific Perspectives on Enjoyment and Suffering, New York: Russel Sage Foundation.

Haile, H. B., Bock, B., \& Folmer, H. (2012). Microfinance and female empowerment: Do institutions matter? Women's Studies International Forum, 35, 256-265. http://dx.doi.org/10.1016/j.wsif.2012.04.001

Hair Jr, J. F., Hult, G. T. M., Ringle, C., \& Sarstedt, M. (2016). A Primer on Partial Least Squares Structural Equation Modeling (PLS-SEM). Sage Publications.

Hamdan, H., \& Hussin, W. S. W. (2012). The importance of monitoring and entrepreneurship concept as future direction of microfinance in Malaysia: Case study in the state of Selangor. Journal of Global Entrepreneurship, 3(1), 1-25. 
Hassan, S., Abdul Rahman, R., Abu Bakar, N., \& Lahsasna, A. (2012, May 9-10). Towards triple bottom lines microfinance institutions (MFIs) - a case study of Amanah Ikhtiar Malaysia (AIM). Paper presented at the International Conference on Excellence in Business, University of Sharjah, UAE.

Hoamid, A. A., Zain, A. Y. M., Al-Matari, Y. A., Minai, M. S., \& Ahmad, F. B. (2017). The Role of Customer-Focused Strategies to Improve Islamic Microfinance Institutions Performance: Empirical Evidence and Lessons from Yemen. International Review of Management and Marketing, 7(1), 291-299.

Hermes, N., Lensink, R., \& Meesters, A. (2011). Outreach and efficiency of microfinance institutions. World Development, 39(6), 938-948.

Huque, M. (2017). Effectiveness of Micro-Credit on Urban Poor Women in Dhaka City: An Empirical Study. International Journal of Research in Humanities and Social Studies, 4(10), 1-8.

Karnani, A. (2007). Microfinance Misses its Mark. Stanford Social Innovation Review, 5(3), 3440 .

Kaur, M. (2016). Urban middle class now $40 \%$ poorer. MToday News Sdn Bhd.

Kireti, G. W., \& Sakwa, M. (2014). Socio-Economic Effects of Microfinance Services on Women: The Case of Rosewo Microfinance, Nakuru County, Kenya. International Journal of Academic Research in Economics and Management Sciences, 3(3), 43-59.

Krejcie, R. V., \& Morgan, D. W. (1970). Determining sample size for research activities. Educational and psychological measurement, 30(3), 607-610.

Li, X., Gan, C., \& Hu, B. (2011). The Welfare Impact of Microcredit on Rural Households in China. The Journal of Socio-Economics, 40(4), 404-411.

Macha, J. J., Chong, Y. L., \& Chen, I. C. (2018). Rural Household's Intention to Use Microfinance in Tanzania. International Journal of Business, 23(2), 198-216.

Mahjabeen, R. (2008). Microfinancing in Bangladesh: Impact on households, consumption and welfare. Journal of Policy modeling, 30(6), 1083-1092.

Matul, M. (2005). Demand for Microinsurance in Georgia: Quantitative Study Results. Microinsurance Centre. http://www.microinsurancecentre.org/component/edocman/ market-development/demand-studies/demand-for-microinsurance-in-georgiaquantitative-study-results.html?Itemid=

Mazvimavi, K., \& Twomlow, S. (2009). Socioeconomic and institutional factors influencing adoption of conservation farming by vulnerable households in Zimbabwe. Agricultural systems, 101(1-2), 20-29.

Mbithi, N. K. (2016). Effectiveness of Microfinance Training Programmes on Women'S Financial Skills in Self-Help Groups in Limuru Constituency (Doctoral dissertation, University of Nairobi). http://hdl.handle.net/11295/100398

Ministry of Finance (2007). Economic Report 2007/2008. Putrajaya: Jabatan Perangkaan Malaysia. Mokhtar, S. H. (2011). Microfinance performance in Malaysia (Doctoral dissertation, Lincoln University, New Zealand). https://researcharchive.lincoln.ac.nz/bitstream/handle/10182/4186/Mokhtar_PhD.pdf

Morduch, J., \& Haley, B. (2002). Analysis of the effects of microfinance on poverty reduction. New York: NYU Wagner Working Paper No. 1014.

Mungai, D. W. (2015). The effect of micro-finance service on the growth of small and medium enterprises in Kajiado County (Doctoral dissertation, University of Nairobi). http://erepository.uonbi.ac.ke/bitstream/handle/11295/94168/Mungai_The?sequence=3 
Mwangi, R. N. (2015). The Effect of Microfinance Services on Economic Empowerment of SmallScale Farmers in Kiambu County (Doctoral dissertation, University of Nairobi). http://erepository.uonbi.ac.ke/bitstream/handle/11295/95213/Mwangi_The\%20Effect\%2 0Of\%20Microfinance $\% 20$ Services $\% 20$ On\%20Economic\%20Empowerment $\% 200 f \% 20$ Small\%20Scale \%20Farmers \%20In\%20Kiambu\%20County.pdf?sequence $=1$

Mwewa, N. M. (2013). The effects of microfinance services on the growth of small and medium enterprises in Machakos County (Doctoral dissertation, University of Nairobi). http://erepository.uonbi.ac.ke/handle/11295/58984

Nader, Y. F. (2008). Microcredit and The Socio-Economic Wellbeing of Women and Their Families in Cairo. The Journal of Socio-Economics, 37(2), 644-656.

Nawai, N., Noor, M. S. Z., \& Shariff, M. N. M. (2011). The Importance of Microfinancing to The Microenterprises Development in Malaysia's Experience. Asian Social Science, 7(12), 226-238.

Okurut, F. N., Banga, M., \& Mukungu, A. (2004). Microfinance and poverty reduction in Uganda: achievements and challenges. (EPRC Research Series No 41). Economic Policy Research Centre. $\quad$ https://www.findevgateway.org/sites/default/files/publications/files/mfg-enpaper-microfinance-and-poverty-reduction-in-uganda-achievements-and-challenges-apr2004.pdf

Omar, M. Z., Noor, C. S. M., \& Dahalan, N. (2012). The Economic Performance of the Amanah Ikhtiar Malaysia Rural Microcredit Programme: A Case Study in Kedah. World Journal of Social Sciences, 2(5), 286-302.

Omoro, N. O., \& Omwange, A. M. (2013). The Utilization of Microfinance Loans and Household Welfare in the Emerging Markets. European International Journal of Science and Technology, 2(3), 59-78.

Owuor, M. A. (2015). Effect of microfinance services on the growth of women owned small and medium enterprises in Ruiru Sub-county (Doctoral dissertation, University of Nairobi). http://erepository.uonbi.ac.ke/bitstream/handle/11295/94142/Owuor_Effect\%20of\%20m icrofinance $\% 20$ services $\% 20$ on $\% 20$ the $\% 20$ growth $\% 20$ of $\% 20$ women.pdf?isAllowed=y \& sequence $=3$

Patten, M. L. (2016). Questionnaire research: A practical guide. USA: Routledge.

Paul, K. N., Nyaga, J., \& Karoki, J. M. (2013). An evaluation of legal, legislative and financial factors affecting performance of women micro entrepreneurs in Kenya. European Journal of Business and Management, 5(8), 16-26.

Rulindo, R., \& Pramanik, A. H. (2013). Finding a way to enhance impact of Islamic microfinance: The role of spiritual and religious enhancement programmes. Developing Country Studies, $3(7), 41-52$.

Saad, N. M., \& Duasa, J. (2010). An Economic Impact Assessment of a Microcredit Program in Malaysia: The Case of Amanah Ikhtiar Malaysia (AIM). International Journal of Business \& Society, 12(1), 1-14.

Salia, P. J. (2014). The Effect of Microcredit on The Household Welfare: Empirical Evidences from Women Micro-entrepreneurs in Tanzania. International Journal of Academic Research in Business and Social Sciences, 4(5), 259.

Sarpong, A. (2014). Multinomial Logistic Analysis of "SUSU" Contribution in Ghana. Ekonomskii Socijalni Razvoj, 1(1), 96-105.

Seng, K. (2017). Rethinking the Effects of Microcredit on Household Welfare in Cambodia. The Journal of Development Studies, 54(9), 1496-1512. 
Shil, P., \& Nath, B. (2013) D. Micro-Insurance-A Step Towards Inclusion of Economically Poor to The Umbrella of Insurance. Prayas-An International Journal of Multidisciplinary Studies (PIJMS) is The First Open Access, 56(1), 1-102.

Tsafe, B. M., \& Rahman, R. A. (2014). Effects of Spirituality on Board Service Performance in Malaysian Microfinance Firms. Journal of Finance, Accounting and Management, 5(1), 675-688.

Wairimu, Z., \& Mwilaria, S. M. (2017). Microfinance Institutions' Social Intermediation and Micro and Small Enterprises Survival in Thika Town, Kenya. Asia Pacific Journal of Multidisciplinary Research, 5(2), 87-93.

Wahid, A. (1994). The Grameen Bank and poverty alleviation in Bangladesh. American Journal of Economics and Sociology, 53(1), 1-15.

World Bank. (2019). The World Bank Statistics: Malaysia. Malaysia: The World Bank. 